\title{
Toward the development of a corporate social responsibility leadership questionnaire: An adaptation of the LBI-2
}

\author{
Authors: \\ Ronel du Preez \\ Liam T. van Zyl ${ }^{1}$ \\ Affiliations: \\ ${ }^{1}$ Department of Industrial \\ Psychology, Stellenbosch \\ University, South Africa

\section{Correspondence to: \\ Ronel du Preez \\ Email:} \\ rdp@sun.ac.za \\ Postal address: \\ Private Bag X1, Matieland \\ 7602 , South Africa

\section{Dates:} \\ Received: 04 Nov. 2014 \\ Accepted: 22 May 2015 \\ Published: 07 Aug. 2015 \\ How to cite this article: \\ Du Preez, R., \& Van Zyl, L.T. \\ (2015). Toward the \\ development of a corporate \\ social responsibility \\ leadership questionnaire: \\ An adaptation of the LBI-2. \\ SA Journal of Industrial \\ Psychology/SA Tydskrif vir \\ Bedryfsielkunde, 41(1), Art. \\ \#1256, 18 pages. http:// \\ dx.doi.org/10.4102/sajip. \\ v41i1.1256

\section{Copyright:} \\ C 2015. The Authors. \\ Licensee: AOSIS \\ OpenJournals. This work is \\ licensed under the Creative \\ Commons Attribution \\ License.
}

\section{Read online:}

Scan this $Q R$ code with your smart phone or mobile device to read online.
Orientation: Corporate social responsibility (CSR) has grown exponentially in South African organisations, making leadership in CSR crucial. This article describes the first phase towards the development of a CSR leadership questionnaire (CSR-LQ), based on the Leadership Behaviour Inventory version 2 (LBI-2).

Research purpose: To develop a CSR leadership questionnaire (the CSR-LQ) that would serve as a basis for developing a CSR leadership competency model in future.

Motivation for the study: Effective leadership in companies' CSR undertakings is imperative. The development of a leadership measure is the first step toward the development of a CSR leadership competency framework.

Research approach, design and method: A three-phase mixed-method ex post facto research approach (qualitative and quantitative) was applied. Purposive sampling included CSR leaders in Phase $1(n=5)$ and Phase $2(n=13)$ to develop the CSR-LQ prior to empirical testing.

Main findings: The CSR-LQ was developed based on the LBI-2. The final version of the CSR-LQ consists of 123 items measuring the leadership competencies in three stages. Stage 1 is creating a CSR vision and strategy (analysing and interpreting the CSR environment; formulating the CSR vision and strategy); Stage 2 is preparing the organisation for implementing the CSR vision and strategy (preparing the leader and organisation members; preparing the organisation) and Stage 3 is implementing the CSR vision and strategy (sharing the CSR vision and inspiring organisation members; leading with integrity and courage; leading with compassion; Leading across boundaries; reviewing and rewarding CSR performance).

Practical/managerial implications: The CSR-LQ could be used to obtain assessment and development of CSR leadership competencies after empirical testing.

Contribution/value-add: This study is the first step towards developing a South African CSR leadership measure that could be used to obtain $360^{\circ}$ assessments of the CSR leadership competencies and form the basis of the development of a comprehensive CSR leadership competency framework.

\section{Introduction}

Business is one of the most powerful forces of change in the 21st century (Carroll \& Shabana, 2010; Ferrell, Thorne \& Ferrell, 2011); however, one of the major challenges facing business today is to harness their potential for change and to accurately allocate resources where they will be most effective and make the biggest difference. Fortuitously, business leaders around the world are increasingly acknowledging that new business models are emerging that can successfully combine responsible citizenship and profitability, increasing returns to shareholders, instead of forgoing them.

In recent years, organisations and the business community have realised that they have responsibilities towards the environment and the communities they operate in and that their responsibilities go beyond that of only making profits for their shareholders. This growing awareness amongst them has caused the concept of corporate social responsibility (CSR) to grow in importance and significance (Carroll \& Shabana, 2010).

\section{CSR can broadly be defined as:}

situations where the firm goes beyond compliance and engages in actions that appear to further some social good, beyond the interests of the firm and that which is required by law. (McWilliams \& Siegel, 2001, p. 118) 
It can also be described as 'a commitment to improve [societal] well-being through discretionary business practices and contributions of corporate resources' (Du, Bhattacharya \& Sen, 2010, p. 8). However, Carroll (as cited in Carroll \& Shabana, 2010) argues that organisations' social responsibilities comprise more than just philanthropic activities. According to Carroll, 'the social responsibility of business encompasses the economic, legal, ethical, and discretionary (later referred to as voluntary) expectations that society has of organisations at a given point in time' (as cited in Carroll \& Shabana, 2010, p. 89).

Businesses in South Africa can play, and more importantly should play, a role in confronting the problems mentioned above. They can align their CSR initiatives to achieve the country's stated goals of reducing poverty, accelerating and sustaining economic growth and providing better goods and services for their citizens in terms of the National Development Plan 2030 (NPC, 2011). Further to this, CSR initiatives that are aligned with socio-economic development initiatives can also contribute towards organisations' BEE scorecard, benefiting all the organisation's stakeholders whilst simultaneously strengthening the organisation's socioeconomic development pillar of the seven pillars of broad-based Black economic empowerment (B-BBEE) (Phillips, 2013).

CSR initiatives have an important role to play in bridging the skills and education gap and overcoming critical socioeconomic, health and educational challenges threatening the growth and well-being of the nation. Apart from being a powerful and positive force for social change, organisations can also gain multifaceted business returns from their CSR endeavours. According to Porter and Kramer (2006, p. 80), 'CSR can be more than a cost, a constraint or a charitable deed; instead, it has turned out to be a source of opportunity, innovation and competitive advantage'.

CSR does not happen spontaneously in organisations. Organisations need to embrace the philosophy of social responsibility and then follow through with the implementation of CSR initiatives. CSR is not only about the organisation giving verbal and written commitment that it will be socially responsible, but requires both action and results. The successful adoption of CSR requires a strategic focus and should form part of the organisation's vision and values and incorporate a multilevel approach over numerous human resource and organisational domains (Aguinis \& Glavas, 2012; Ferrell et al., 2011; Morgeson, Aguinis, Waldman \& Siegel, 2013).

In order for CSR to be successful, strategic coordination and collaboration are needed between the organisation's various departments and business units, as well as with relevant stakeholders. Resulting from the need for coordination, large organisations that are committed to CSR usually create specific positions or departments tasked with coordinating the various components of their CSR initiatives. Mediumsized organisations might give a senior executive the additional responsibility to oversee social responsibility, whilst in a very small business the owner will most likely make decisions regarding social responsibility (Ferrell et al., 2011).

Therefore, it is the responsibility of the human resources (HR) department to ensure that a CSR leader is successful and productive in their work role and is achieving the desired CSR outcomes, such as fulfilling the organisation's economic, legal, ethical and voluntary responsibilities to society. However, to provide the CSR leader with the necessary support and resources to be successful in their work role and achieve the desired CSR outcomes, the HR department needs to identify the leadership competencies that a successful CSR leader needs to display. Aguinis and Glavas (2012, p. 956) together with Morgeson et al. (2013) acknowledge that HR management and industrial-organisational psychology can 'make an important contribution in guiding CSR research in such areas as culture change and leadership' in order to address some of the gaps in the research agenda.

\section{Research objective}

The overarching objective of this study is to develop a first version of a CSR leadership questionnaire (CSR-LQ) that would serve as basis for developing a CSR leadership competency model in future. Specific objectives are firstly to derive CSR leadership behaviours or competencies from available literature on leadership and CSR and secondly to develop a first version of a CSR leadership measure that could form the basis of further empirical testing to be ultimately used to obtain $360^{\circ}$ assessments of the CSR leadership competencies.

\section{Literature review Corporate social responsibility defined}

In the literature, a wide variety of definitions of CSR are reported. The multilevel and multidisciplinary nature of CSR including the predictors, outcomes, mediators, and moderators are extensively discussed by Aguinis and Glavas (2012). For succinctness, the authors will thus only highlight the definition of CSR that was used as the basis for scale development in this study.

Carroll (1991) created a four-part definition that defines CSR as follows:

The social responsibility of business encompasses the economic, legal, ethical, and discretionary (later referred to as voluntary) expectations that society has on organisations at a given point in time. (p. 283)

This definition is useful in that it specifies the organisation's economic responsibility as a factor to be considered in CSR and viewing an organisation's corporate responsibility as inseparable from its economic function (Carroll \& Shabana, 2010; Inyang, Awa \& Enuoh, 2011). The socially responsible business can thus be viewed as one that attempts to minimise 
its negative effects on society, whilst at the same time utilising its resources in such a way to maximise its positive effects.

The economic responsibilities of a business include producing goods and services that society wants, at a price that maintains the business, whilst at the same time satisfying its obligations to its shareholders (Carroll \& Shabana, 2010; Matten, Crane \& Chapple, 2003). Legal responsibilities refer to the positive and negative obligations businesses have by law and through regulations in the society in which it operates. Thus, it refers to obeying the laws and regulations of society (Carroll \& Shabana, 2010; Ferrell et al., 2011; Van den Ende, 2004). Ethical responsibilities comprise meeting other societal expectations not written in the law, whilst voluntary responsibilities (philanthropic) are additional behaviours and actions that society finds desirable and which complement the business's values (Ferrell et al., 2011).

Carroll (1991) developed the notion of CSR more explicitly when he contended that the economic and legal responsibilities of an organisation can be considered as those that society requires from them, the ethical responsibilities are those that society expects from them and the voluntary responsibilities are those that society desires from them. A distinction was thus made between the traditional responsibilities of organisations, which are embodied in their economic and legal responsibilities towards society, and the new responsibilities of organisations, which are embodied in their ethical and voluntary responsibilities and reflect the new, broader, social contract between organisations and society (Carroll \& Shabana, 2010). For the purpose of this study and the development of a CSR leadership measurement instrument, Carroll's four-part definition of CSR is used.

\section{The intersection between CSR and leadership}

After a comprehensive leadership literature review covering the trait theories, behavioural theories, contingency theories and the neo-charismatic theories, it was evident that the theories of the neo-charismatic leadership paradigm are especially useful when identifying the competencies that are necessary to be a successful CSR leader, as the focus is on the behaviours that constitute outstanding leadership (Robbins, Odendaal \& Roodt, 2003).

Strand (2011) carried out a review of existing research relating leadership to CSR with the primary goal to try and better understand the intersection between the two fields and to identify potentially fruitful avenues of future research. His review indicates that a number of researchers have explored the relationship between leadership and CSR in terms of the neo-charismatic leadership theories, including transformational leadership (e.g. Egri \& Herman, 2000; Lacerda, 2010; Shahin \& Zairi, 2007; Waldman, Siegel \& Javidan, 2006, as cited in Strand, 2011), transactional leadership (e.g. Szekely \& Knirsch, 2005, as cited in Strand, 2011) and visionary leadership (e.g. Waldman, De Luque, Washburn \& House, 2006; Ketola, 2006, as cited in Strand, 2011). Strand noted that Waldman, Siegel and
Javidan's (2006) exploration of transformational leadership factors and how they relate to CSR activities 'represents one of the more thorough, descriptive studies' (p. 91) regarding the intersection of the two fields.

In 2006, Waldman et al. investigated the potential link between CEO transformational leadership factors in 112 large US and Canadian companies and the CSR actions of their respective firms. Citing an absence of independence between the two emotional factors idealised influence and inspirational motivation (Waldman et al., 2006, p. 1706), they examined both as a single emotional factor termed 'charismatic leadership'. The intellectual factor intellectual stimulation was also examined, but the factor individualised consideration was excluded due to conceptual complications in connecting individual-level focus with the higher-level organisational occurrence of CSR.

Waldman et al. (2006) report a positive relationship between CEO intellectual stimulation and the firm's tendency to engage in strategically-oriented CSR, but not socially-oriented CSR. According to Waldman et al., the results suggest that intellectually stimulating leaders not only attempt to practise corporately responsible actions, but also aim their efforts at areas that are most pertinent to the firm's strategic objectives. However, in contrast to what was hypothesised, Waldman et al. found no statistically significant relationship between CEO charismatic leadership and CSR, proposing that the laudable features of charismatic leadership that are emphasised in the literature may not actually lead to corporately responsible actions.

Building on the work of Waldman et al. (2006), Lacerda (2010) investigated the relationship between CEO transformational leadership and CSR in 50 large Portuguese firms representing different sectors. Lacerda examined all four transformational leadership dimensions as outlined by Bass and Avolio (2008), as well as an additional dimension ethical integrity as described by Turner, Barling, Epitropaki, Butcher and Milner (2002). The study found that transformational leadership correlated positively with firm strategic orientation to CSR, with specifically the two dimensions inspirational motivation and individualised consideration strongly linked to firm strategic orientation to CSR. Idealised influence and intellectual stimulation were not found to be significant predictors of firm strategic orientation to CSR. Despite the theoretical background linking the two (Lacerda, 2010, p. 30), it was found that ethical integrity is not significantly related to firm strategic orientation to CSR, implicating that a leader's ethical integrity is not significantly linked to the adoption of CSR practices (Lacerda, 2010).

In 2009, Kakabadse, Kakabadse and Lee-Davies conducted research that focused on both the leadership skills and capabilities needed to effectively implement CSR in organisations. They presented a model that included how to implement and drive CSR through organisations, outlining three stages of CSR implementation and identifying the 
different leadership skills that would be needed in each stage. The three stages of CSR implementation identified by Kakabadse, Kakabadse and Lee-Davies (2009) are the decision-making stage, the adoption stage and the commitment stage. In the first stage, the decision-making stage, the CSR leader comes to terms with the need for personal growth and organisational movement towards CSR. This is followed by the adoption stage, in which real movement begins and starts to impact the CSR leader's organisation. Finally, the commitment stage is reached when it becomes clear that the organisation is committed to CSR in the long run and that CSR goals will be constantly pushed in spite of obstacles such as opposition by shareholders, complications in measuring CSR and conflicting priorities. Specific CSR leadership skills and capabilities needed in each of the three stages were also identified, each fulfilling its own role in the effort to achieve CSR and together signifying a coherent whole that offers the channel for organisations to accomplish CSR. In total 10 leadership capabilities were identified, namely CSR awareness and reflexivity in stage 1, discerning CSR goals, using business case language, persuasion, handling paradoxes and conflicting priorities, consistency of application, CSR measurement and follow-through in stage 2 and the will to act in stage 3 . The three-stage model thus represents a journey to effectively implement CSR in organisations and is based on two important components, namely:

- The CSR leader thoroughly develops different phases with their organisation: from a position characterised by much uncertainty and ambiguity in understanding CSR to a new and tangible reality characterised by purposeful leadership action.

- The CSR leader needs different capabilities at the different developmental phases in order to successfully move the organisation's CSR forward (Kakabadse et al., 2009).

According to Kakabadse et al. (2009), all 10 leadership capabilities are interconnected and they often need to be used in conjunction with one another to face the unavoidable challenges confronting the implementation of CSR in organisations. Truly effective CSR leadership, which succeeds in fully implementing CSR in organisations, requires the responsible individual to use all the capabilities together, allowing the organisational leaders to act in a consistent way that makes sense to external stakeholders and drive the organisation forward. Kakabadse et al. came to the conclusion that CSR leadership can be developed, but that learning to master the skills needed to perform in each stage to successfully implement CSR in organisations can be challenging. They also acknowledge that observers may perceive their CSR leadership model as being borne of essentially charismatic leadership qualities that can be developed by individuals.

The available literature on the intersection between CSR and leadership thus shows that a number of researchers have explored the relationship between leadership and CSR in terms of the neo-charismatic leadership theories. The most thorough study is Waldman et al.'s (2006) exploration of transformational leadership factors and their relationship to CSR activities. This study concluded that transformational leadership is positively related to a firm strategic orientation to CSR. The studies by Waldman et al. and Lacerda (2010) therefore support the earlier notion that the theories of the neocharismatic paradigm - and especially the transformational leadership theories - are useful when explaining the link between leadership and CSR and can be used as basis for identifying the CSR leadership competencies necessary to be an effective and successful CSR leader.

\section{The Leadership Behaviour Inventory and Leadership Behaviour Inventory version 2}

In 2002 Spangenberg and Theron developed a uniquely South African leadership questionnaire, the Leadership Behaviour Inventory (LBI) to assess, in terms of the South African organisational context, a wide range of capabilities required by leaders and managers to implement change whilst maintaining unit performance. This questionnaire incorporates numerous leadership theories (referred to earlier). Spangenberg and Theron (2002) argue that the leadership behaviours (competencies) identified by their model best describe the leadership behaviours that are necessary to be a successful and effective leader.

Spangenberg and Theron (2002) considered leadership effectiveness of critical importance whilst developing the LBI and felt that 'leading change' and 'ensuring effective organisational unit performance' were the most important aims of leadership in the South African organisational context (Spangenberg \& Theron, 2002, p. 12). It was also postulated that the instrument should assess leadership and the change process in stages. Furthermore, the LBI should have the ability to measure the full range of behaviours required to successfully manage the change process, whilst reflecting the diversity of South Africa's managerial population (Spangenberg \& Theron, 2010).

The LBI is based on a comprehensive interpretation of the leadership construct, containing elements of leadership, management and supervision (Spangenberg \& Theron, 2010). Charismatic or transformational leadership (general leadership) forms the core of the LBI leadership construct, whilst elements of management and supervisory leadership also make a significant contribution to the construct (Spangenberg \& Theron, 2010).

Based on the compelling need for change and transformation in South Africa, Spangenberg and Theron (2002) thought it was important for the LBI to be based on theory from the neo-charismatic leadership paradigm. Eleven generic behaviours outlined by House (1995), which the author believed characterised outstanding leadership, formed the theoretical background of the LBI dimensions. A review of the literature also indicated that Conger and Kanungo's (1987) model of charismatic leadership (as cited in Spangenberg \& Theron, 2002), also known as the C-K model, conceptually best satisfied the demands of the South African context and 
served as the launching pad for the LBI development. The C-K model comprises three stages, namely the environmental assessment stage, the vision formulation stage and the implementation of vision stage (refer to Van Zyl, 2013, for a comprehensive discussion of the C-K model).

In addition to the three stages of the C-K model, Spangenberg and Theron (2010) decided to include an additional leadership role in their model due to the 'absence of sufficient infrastructure in stage 3 ' (p. 49). They argued that the group of behaviours categorised under empowerment was not adequate to guarantee that the desired changes would in fact be implemented. Nadler and Tushman (1990) echo the importance of infrastructure in implementing vision in complex organisations and suggest that instrumental leadership be utilised to supplement charismatic leadership. According to Nadler and Tushman, the aims of instrumental leadership include building competent teams, clarifying necessary behaviours, integrating measurement and administering rewards and punishments so that individuals view behaviours that are in line with the change as essential for them to fulfil their own goals. Furthermore, Nadler and Tushman point out that, in order to implement instrumental leadership, three elements of behaviour are required - namely structuring, controlling and rewarding that are complementary to charismatic leadership (which includes envisioning, energising and enabling). However, Spangenberg and Theron (2002) point out that the success of any leader 'will ultimately be evaluated in terms of unit performance that ... cannot be achieved without attention to the visionary and motivational aspects of leadership, combined with instrumental leadership' (p. 12).

The first generation LBI model comprised four phases measured by 24 dimensions (Spangenberg \& Theron, 2002). After the instrument was extensively used and its psychometric properties evaluated, the original LBI was accordingly revised to a more streamlined, secondgeneration inventory (LBI-2) by reducing the four stages to three and by decreasing the number of dimensions from 24 to 20 . The focus now turns to the research design followed in the current study.

\section{Research design Research approach}

The study made use of a mixed-method ex post facto research approach, which included both qualitative and quantitative phases. Netemeyer, Bearden and Sharma's (2003) scale development framework was used as a point of departure for the development of the CSR-LQ and a three-phase research methodology was developed for this study as depicted in Figure 1.

\section{Phase 1: Construct definition and domain specification}

During Phase 1 of the development of the CSR-LQ, CSR leadership as a construct was defined. This was done through

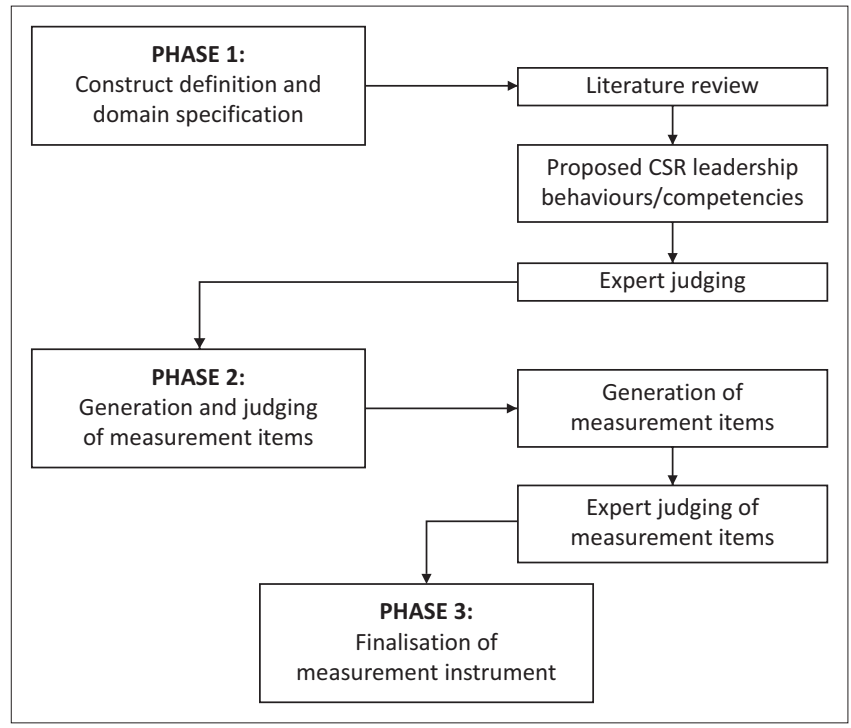

FIGURE 1: Corporate social responsibility leadership questionnaire (CSR-LQ) development process prior to empirical testing.

conducting a literature review and making use of expert judging with the help of the basic principles of the critical incident technique (CIT).

After doing an extensive literature review, the LBI-2 was identified to form the basis for the development of the CSRLQ. The dimensions of the LBI-2 were adapted for CSR leadership and served as starting point for the development of the CSR-LQ (see Table 1).

The adapted LBI-2 dimensions were subjected to expert judging by five CSR leaders as an aid for establishing face and content validity. Respondents were asked to indicate the relevance, specificity, representativeness and clarity of dimensions and no changes to the 20 dimensions were proposed (refer to results and discussion). The basic principles of the CIT developed by Flanagan (1954) were subsequently used to gain insight into CSR leadership and served as the basis for the generation of new items for the CSR-LQ (in Phase 2). This technique was especially useful in this study, as 'critical incident' refers to any behaviour that can be observed (Flanagan, 1954) and could therefore be used as basis for the development of new items for the CSR-LQ.

Over the years the CIT has advanced in two major ways. According to Butterfield, Borgen, Amundson and Maglio (2005), the CIT has firstly moved from being mainly behaviourally based to also include the study of psychological states or experiences. Secondly, there was a shift in emphasis by experts from direct observation to an incorporation of reflective self-report.

Although these two changes in the CIT have been shown to be fruitful in various research studies, it also brought along some challenges in the form of increased subjectivity during the gathering of data. The problem can be addressed through the implementation of credibility checks during the CIT process. Borgen, Amundson and Butterfield (2008) did 
TABLE 1: Adapted LBI-2 stages, leadership roles and dimensions for CSR-LQ.

\begin{tabular}{|c|c|}
\hline Stages & Leadership roles and dimensions \\
\hline \multicolumn{2}{|l|}{ STAGE 1: Creating a CSR vision and strategy } \\
\hline \multirow[t]{2}{*}{ Analysing and interpreting the CSR environment } & 1. Monitoring the external CSR environment \\
\hline & 2. Monitoring the internal CSR environment \\
\hline \multirow[t]{3}{*}{ Formulating the CSR vision and strategy } & 3. Developing a challenging CSR vision \\
\hline & 4. Conceptualising CSR strategy \\
\hline & 5. Developing CSR performance plans \\
\hline \multicolumn{2}{|c|}{ STAGE 2: Preparing the organisation for implementing the CSR vision and strategy } \\
\hline \multirow[t]{3}{*}{ Preparing the leader and organisation members } & 6. CSR leader self-discovery, reflection and self-awareness \\
\hline & 7. CSR leader personal growth and development \\
\hline & 8. Empowering organisational members \\
\hline Preparing the organisation & 9. Optimising processes and structures \\
\hline \multicolumn{2}{|l|}{ STAGE 3: Implementing the CSR vision and strategy } \\
\hline \multirow[t]{2}{*}{ Sharing the CSR vision and inspiring organisation members } & 10. Articulating the CSR vision \\
\hline & 11. Inspiring and motivating organisation members \\
\hline \multirow[t]{3}{*}{ Leading with integrity and courage } & 12. Building trust and demonstrating integrity 12 \\
\hline & 13. Demonstrating decisiveness and hardiness \\
\hline & 14. Acting entrepreneurial \\
\hline \multirow[t]{2}{*}{ Leading with compassion } & Showing concern for others \\
\hline & 16. Displaying sound interpersonal skills \\
\hline \multirow[t]{2}{*}{ Leading across boundaries } & 17. Facilitating interdepartmental coordination \\
\hline & 18. Influencing across external boundaries \\
\hline \multirow[t]{2}{*}{ Reviewing and rewarding CSR performance } & 19. Reviewing CSR performance \\
\hline & 20. Acknowledging and celebrating CSR performance \\
\hline
\end{tabular}

CSR, corporate social responsibility

Source: Adapted from Spangenberg, H.H., \& Theron, C.C. (2011). LBI-2 development report: Leadership report and planning guide. Pinegowrie: Jopie van Rooyen, pp. 4-6.

a comprehensive review of the CIT literature and outlined five key steps and credibility checks (to minimise the effect of subjectivity of data gathering) in the CIT process.

Step 1: Ascertain the general aims of the activity to be studied. This step is closely linked to the research question, referring to the activity or construct that the researcher wishes to observe or have research participants self-report on.

Step 2: Make plans and set specifications. Four specifications need to be established and communicated before collecting the data, namely (1) defining the types of situations that need to be observed or reported on, (2) determining the situation's relevance to the general aim of the study, (3) gathering a complete understanding of the extent of the situation's effect on the general aim and (4) determining who will make the observations or take part in the self-reporting.

Step 3: Collect the data. The collection of data can be done by supervisors or experts in the particular field through the direct observation of people performing the activity or through subject experts recalling past incidents or experiences. The latter can be done through personal or telephone interviews or by making use of a questionnaire. For the purpose of this study, interviews were conducted with five CSR leaders to collect the initial data. For optimal data collection during such an interview, it is very important that a good relationship is established at the beginning of the interview. This will build trust between interviewer and interviewee, generally making the interviewee more comfortable to share information with the researcher (Miczo, 2003). After a relationship was established, the research participants were asked to recall the critical incidents that helped or hindered them in their role, the meaning of these incidents to them and the outcome of using the critical incidents by giving a practical example (if possible). This was done with the help of an interview schedule based on the CIT interview guidelines outlined by Latham and Wexley (1994) (refer to Addendum A in Van Zyl, 2013).

Step 4: Analyse the data. The process of analysing the data entails (1) determining the data's frame of reference that surfaces as a result of its intended use, (2) formulating the different categories by means of an inductive process and (3) determining the degree of specificity or generality that is going to be used when reporting the data. Thus, a framework with different categories and operational definitions is built according to which the data can be organised for analysis.

Step 5: Interpret the data and report the results. A sequence of nine credibility checks can be used to establish the trustworthiness of the results of a CIT analysis:

1. A check to guarantee accuracy and afford descriptive validity is to audiotape or videotape the interviews.

2. Interview fidelity ensures that the method is being followed when a CIT expert listens to a sample of interview recordings.

3. Critical incidents from $25 \%$ of the interviews are independently extracted by someone during independent extraction of critical incidents.

4. Exhaustiveness tracks the end of new categories coming from the developing category scheme.

5. The percentage of participants who mention incidents in a particular category is checked through participation 
TABLE 2: Demographic profile of research participants: Phase 1.

\begin{tabular}{|c|c|c|c|c|c|c|c|c|}
\hline Participant & Industry $\dagger$ & Job title & $\begin{array}{l}\text { Tenure } \\
\text { (years) }\end{array}$ & $\begin{array}{l}\text { Experience in } \\
\text { CSR (years) }\end{array}$ & Gender & Age & First language & Highest qualification \\
\hline 1 & Arts, entertainment and recreation & CSR manager & 2 & 8 & Female & 37 & English & Diploma (Human Resource Management) \\
\hline 2 & Manufacturing & CSR executive & 9 & 13 & Female & 40 & English & Diploma (Secretarial) \\
\hline 3 & Financial and insurance activities & $\begin{array}{l}\text { Foundation } \\
\text { manager }\end{array}$ & 2 & 7 & Female & 32 & English & $\begin{array}{l}\text { Postgraduate diploma (Management, } \\
\text { Strategic Social Engagement) }\end{array}$ \\
\hline 4 & Information and communication & $\begin{array}{l}\text { Group CSI } \\
\text { coordinator }\end{array}$ & 8 & 8 & Female & 37 & Afrikaans & $\begin{array}{l}\text { Bachelor's degree (Public Relations } \\
\text { Management) }\end{array}$ \\
\hline 5 & Human health and social work activities & CSI manager & 3 & 3 & Male & 31 & isiXhosa & BComm (Marketing Management) \\
\hline
\end{tabular}

CSR, Corporate social responsibility leadership questionnaire

$\dagger$, Industries are classified according to Statistics South Africa (StatsSA). (2012). Standard industrial classification of all economic activities (SIC). (7th edn.). Pretoria: StatsSA.

rate (the required participation rate for a category to be deemed viable is $25 \%$ ).

6. An independent judge puts $25 \%$ of critical incidents into the category scheme and determines the match rate during independent placement of incidents into categories (for the categories to be deemed credible a match rate between $75 \%$ and $85 \%$ is required).

7. A second interview with participants reviews the accuracy of the critical incidents and categories developed from first interviews during participant cross-checking.

8. Experts in the field are requested to review the categories and remark on the efficacy thereof in terms of what is surprising and what is missing during expert opinions.

9. Theoretical agreement makes the assumptions underlying the project explicit and compares the category schemes with appropriate literature (Borgen et al., 2008).

The utilisation of these credibility checks ensures that the results obtained are accurate and a reflection of the job requirements or human behaviours critical for success in the occupational field being studied and positions them in the broader research and professional community (Borgen et al., 2008).

During the development of the first draft of the CSR-LQ, all the five steps were followed; however, only two of the checks listed above (numbers 1 and 5) were performed given the constraints of the study. This could be regarded as a limitation in the current study and is reported as such.

Purposive sampling was utilised to identify the five research participants (refer to Table 2) that participated in Phase 1 of the measurement instrument development process.

\section{Phase 2: Generation and judging of measurement items}

The second phase of the CSR-LQ development involved the generation of items for the questionnaire, as well as the expert judging of the pool of measurement items. There were various sources of items; the main source of items was the LBI-2. Minor adaptions to the LBI-2 items were made, based on the results obtained from the first phase of the scale development process, as well as from the literature on CSR and leadership.

Minghat, Yasin and Udin (2012) posit that the Delphi technique can essentially be described as the use of expert opinion, with the main objective of acquiring highly reliable responses towards problems and surveys given to a panel of experts. The authors acknowledge that they cannot claim that the Delphi technique was applied in accordance with all four guidelines as proposed by Su, Win, \& Chung (2010), which include anonymity, iteration, controlled feedback and calculating each content validity index and the aggregation of group answers. However, some basic principles of the Delphi technique were used to judge the relevance of the newly adapted measurement items and to propose changes.

A panel comprising of 13 individuals (selected by means of purposive sampling and snowball sampling) who are experts in either the academic field of CSR, or who are active in the private sector as CSR leaders, participated in the judging of the CSR-LQ measurement instrument. The importance of the selection of experts is also emphasised by $\mathrm{Su}$ et al. (2010, p. 702) in that they state that 'selecting "experts" as the participants of the Delphi group are very important because they need to understand and have experiences which are related to the specific research theme of performing such method'.

The pilot questionnaire was sent out to the selected respondents electronically. They were requested to indicate the importance of each item with regard to CSR leadership on a five-point Likert-type scale ranging from 1 (not at all important) to 5 (absolutely critical). Respondents were afforded the opportunity to give additional comments about specific items (e.g. appropriateness, domain representation, domain relevance, wording, grammar, clarity and comprehensiveness). The guideline of iteration (having respondents reconsider their responses at least twice to reach consensus) could not be met due to the sample constraints of the study.

\section{Data recording and analysis}

All the qualitative data (comments on items) obtained were entered into a Microsoft Excel file template, whilst all the quantitative data (Likert ratings) were transferred into a CSV file for further statistical analysis. Firstly, the comments provided by the expert judges on specific items were studied and used to improve certain items or to identify and delete duplicate items in line with the basic principles of the Delphi technique. Secondly, descriptive statistics were conducted on the item ratings with the help of the software STATISTICA (version 8.0) and the deletion of items was based mainly on numerical decision rules. 
The means and the standard deviation were applied to identify the items that qualified for deletion based on the numerical decision rules. Netemeyer et al. (2003) suggest that when judging items for content and face validity, only items with high inter-judge agreement be retained. A decision rule sensitive to interjudge agreement was therefore needed to identify items that needed to be retained or deleted. Based on these guidelines the criteria for inclusion of items based on the descriptive statistics were a mean score greater than 3 and standard deviation less than 1.

\section{Phase 3: Finalisation of the CSR-LQ prior to empirical testing}

After the successful completion of the first and second phases, the final version of the questionnaire was developed.

\section{Ethical considerations}

The ethical considerations in terms of procedures, consent and data protection were adhered to and cleared by the ethical committee of Stellenbosch University.

\section{Results and discussion \\ Phase 1: Construct definition and domain specification}

The literature review and expert review process culminated in the adaption of the LBI-2 for CSR leadership as presented in Table 1. It is argued that each of the leadership dimensions is relevant to CSR leadership and that the LBI-2 contains leadership competencies or behaviours that are also essential for successful and effective CSR leadership in organisations. In the following sections, arguments are presented as to why each CSR competency is a prerequisite to achieve the objectives of CSR. These arguments are essentially adaptations of the arguments posed by Spangenberg and Theron (2011) in the development of the LBI-2 and they serve to motivate the inclusion of each of the LBI-2 dimensions in the development of a CSR leadership measurement instrument.

\section{Monitoring the external environment}

Most organisations, to varying degrees, are affected by changes in the external environment (Spangenberg \& Theron, 2011). It is reasonable to argue that this also applies to the organisation's CSR policies and practices and that organisations must actively scan the CSR environment and monitor CSR trends. Examples of environmental changes and trends that might have an influence on an organisation's CSR endeavours include new legislation or changes to existing legislation (e.g. BBBEE legislation), keeping up to date with revisions to South Africa's Code of and Report on Governance Principles (King III report), sustainability policies and practices of companies listed on the Johannesburg Stock Exchange Social Responsibility Index (JSE SRI), as well as customers' increasing demand for environmentally friendly products and services. Changes in the needs of the organisation's stakeholders also need to be taken into consideration when scanning the external environment. According to Mishra and Suar (2010), it is important for organisations to constantly be aware of the CSR needs of their stakeholders in both the internal and external business environment, as these CSR needs can play a powerful role in increasing and decreasing the organisation's overall performance.

Therefore, the CSR leader needs to keep in touch with developments in the external environment and needs to constantly stay up to date with the latest CSR trends and to check for available resources, opportunities and constraints that may have an impact on the organisation's CSR and its CSR performance. By understanding the relevant changes in the external environment, it is hypothesised that the CSR leader will be able to create a suitable, compelling vision, as well as a CSR strategy that will create and sustain the organisation's competitive advantage.

\section{Monitoring the internal environment}

In addition to monitoring and understanding the external environment of the organisation, it is also important to have insight into the organisation's internal dynamics, resources and constraints (Spangenberg \& Theron, 2011). Luo and Bhattacharya (2006, p. 16) state that 'it is important for managers to consider CSR initiatives in the light of the firm's corporate abilities'. This is because organisations can lose some of their market share when their CSR initiatives are misaligned with internal organisational factors (Luo \& Bhattacharya, 2006). Thus, by carefully examining and combining the information from both the external and internal environments, the CSR leader will be able to create a challenging and realistic CSR vision, as well as develop effective CSR strategies that are aligned with the organisation's internal dynamics, resources and constraints.

\section{Developing a challenging vision}

Harari (1997) states that:

vision should describe a set of ideals and priorities, a picture of the future, a sense of what makes the company special and unique, a core set of principles that the company stands for, and a broad set of compelling criteria that will help define organisational success. (p. 28)

A leader should therefore play an important role in identifying and shaping an organisation's vision.

According to Were (2003), formulating a clear CSR vision plays an important part in implementing CSR in organisations. This view is supported by Strandberg and Principal (2009), who did a review of the available research and found that a key factor of the successful implementation of CSR in organisations is having a vision that incorporates CSR.

A CSR-conscious leader needs to be able to take control and decide what the organisation's future ideals and priorities concerning CSR are. These CSR ideals and priorities need to be incorporated into the organisation's vision. Thus, the CSR leader can develop a potentially successful CSR vision. 
After a vision has been created, it makes sense that a strategy can be conceptualised to achieve the desired CSR vision. A crucial part of this strategy is to articulate a clear CSR vision to the organisation's members. The CSR leader must keep the CSR vision alive in the hearts and minds of organisational members and create an environment in which they are free to pursue diverse ideas and opportunities that serve the CSR vision.

\section{Conceptualising strategy}

It is not unreasonable to hypothesise that, after the leader has created a challenging CSR vision for the organisation, a clearly defined CSR strategy needs to be developed. According to Strandberg and Principal (2009, p. 12), 'once the vision, mission and values framework is defined, the firm is ready to undertake the development of its CSR strategy'. Therefore, a clear CSR strategy can be developed from a clearly defined vision, mission and values framework. A clear CSR strategy is needed to ensure that all employees know what is expected of them with regard to achieving the organisation's CSR goals and to ensure that the required resources are mobilised when and where they are needed (McElhaney, 2009). It is important that this strategy is created in collaboration with key players in the organisation and that it is aligned with the organisation's overall vision and goals. The strategy must contain the organisation's CSR goals and objectives and must clearly spell out how the organisation is going to achieve the stated vision. The strategy should contain information such as the resources needed to successfully implement CSR programmes and initiatives and the actions that need to be taken to achieve the organisation's CSR vision.

\section{Developing performance plans}

In order to successfully implement the CSR vision, the CSR leader must be able to devise and manage an all-inclusive performance plan for each member of the organisation, thus guiding their behaviour in support of the vision. Strandberg and Principal (2009) state that the implementation of CSR can be supported at the individual and team levels through integrating CSR into job descriptions, performance plans and annual performance objectives. Furthermore, it is argued that planning and organising should form a key part of such a performance plan and that human, financial and operational resources must be effectively mobilised in order to support the performance at all levels of the organisation. Thus, in order to successfully implement the organisation's desired CSR vision, it is believed that comprehensive planning is a necessity and should include all three levels.

\section{Leader self-discovery, reflection and self-awareness}

It is postulated that in order to support outstanding performance from followers and to effectively implement the desired vision, the CSR leader must improve themselves on a continuous basis to enhance their own leadership ability, whilst improving the ability and motivation of followers.
Therefore, the CSR leader needs to have a genuine and accurate understanding of their current developmental level and be aware of their personal and leadership strengths and weaknesses. By having a strong self-awareness, the CSR leader is able to pay attention to those areas that are essential for their personal wellness and growth, as well as for success as a CSR leader.

\section{Leader personal growth and development}

The CSR environment is constantly changing, with international and local CSR standards and practices being revised on a continual basis (Ferrell et al., 2011; Pedersen, 2006). It is therefore reasonable to argue that the organisation's vision must be adjusted on a continual basis to keep up with the changes and to stay competitive. The challenges these changes pose require the CSR leader to go through a continuous process of learning, personal change and leadership development to grow as the CSR environment changes.

\section{Empowering followers}

Just as the CSR leader is required to continuously engage in self-development, it is maintained that it is also necessary for the other members of the organisation to develop and maintain the required occupational skills and abilities needed to effectively perform their work. As a result, the CSR leader should actively promote learning amongst employees and should create suitable organisational conditions and a working culture in which employees can fully apply themselves. According to Spangenberg and Theron (2011), empowering employees will have a positive effect on their self-efficacy and may improve morale and motivation amongst unit or department members. Thus, the CSR leader should proactively facilitate the development of relevant, substantive knowledge, skills and abilities in followers.

\section{Optimising processes and structures}

The CSR leader should ensure that the organisation's core processes, systems and structures support the successful execution of the organisation's CSR vision and the smooth implementation thereof. The structures and processes must reflect the nature of the external and internal environment in which the CSR strategy will be implemented.

\section{Articulating the vision}

In order for the leader's CSR vision to be achieved, it is important that the CSR vision is communicated in a way that is easily understood and, consequently, adopted by the members of the organisation. According to Maon, Lindgreen and Swaen (2009, p. 79), the leader 'must communicate the [organisation's socially responsible] vision in an inspiring way so that employees act accordingly'. It is believed that the CSR leader must articulate the vision in such a way that it conveys the idea as a desirable and attainable goal. It should be communicated in such a way that it awakens a sense of excitement amongst organisational members to work towards the realisation of the vision. 


\section{Inspiring and motivating followers}

It is essential for the CSR leader to be able to inspire followers and to raise their expectations in order to improve their motivation, self-confidence and performance levels. It is hypothesised that the CSR leader can develop both follower identification with the organisation and the values inherent in the vision through a positive self-presentation and conveying the vision in an enthusiastic way.

\section{Building trust and demonstrating integrity}

In order for a leader to be effective, it is essential that organisation members have trust in them as well as their vision. This level of trust will motivate the employees to perform beyond expectation (House, 1995; Podsakoff, MacKenzie, Moorman \& Fetter, 1990; Yukl, 2010). In this context, trust refers to the readiness of organisational members to follow the leader in their pursuit of the company's vision, as the leader is viewed as suitably capable to reduce the risk of possibility of failure (Spangenberg \& Theron, 2011). This could hold true for CSR leadership. Through actions, it is believed that the CSR leader demonstrates to organisational members that they can be relied on, which in turn leads to the leader building trust in themself. When there is sufficient trust in the CSR leader, it is argued that organisation members will identify with the vision and values of the CSR leader and will work towards successfully implementing the organisation's CSR vision.

\section{Demonstrating decisiveness and hardiness}

In order to inspire and motivate followers towards the implementation of a vision that may differ greatly from current realities and, thus, have the possibility to encounter resistance, a leader needs strong self-confidence and needs to display decisiveness and hardiness (House, 1995; Spangenberg \& Theron, 2011). It is argued that the same is true for CSR leadership and that the CSR leader needs to have a strong belief in the CSR vision, as well as the ability to take difficult decisions and execute them suitably.

\section{Acting entrepreneurial}

The CSR leader can support the implementation of the CSR vision by acting entrepreneurially. By promoting new ideas, making use of opportunities and embracing change, it is believed that the CSR leader will drive the process of implementing the CSR vision and strategy forward. By taking risks and by modelling innovative behaviour, the CSR leader will serve as symbol to organisational members that they are personally invested and committed to the organisation's CSR vision.

\section{Showing concern for others}

In order to successfully implement the vision, change is required in the business processes and systems. These changes often require employees to change their own beliefs and values (Spangenberg \& Theron, 2011). It is reasoned that in order for the CSR leader to successfully instil the values necessary for this change, a trusting and caring relationship with organisational members is needed. When these conditions are met, organisational members may identify with the CSR leader as someone whom they admire and whose life is worthy of being imitated. Over a period of time, they will internalise the leader's values and vision. The CSR leader can expedite this process of internalisation by consistently showing concern and empathy and by demonstrating an understanding and concern for their needs, feelings and aspirations.

\section{Displaying sound interpersonal skills}

There is a very high likelihood that the organisation's CSR department or unit will consist of a highly diverse staff. Consequently, it is argued that, in order to accomplish the organisation's CSR vision, the CSR leader must be able to unite individuals from diverse backgrounds around the unit's vision and must be able to facilitate productive cooperation between members through good interpersonal skills.

\section{Facilitating interdepartmental coordination}

Fuller (2008) suggests that the successful implementation of CSR initiatives relies heavily on interdepartmental cooperation between different departments. It is maintained that in order to gain a full understanding of the broader CSR context of the organisation, it is important that the CSR leader works across different departments or sections and creates an open system to facilitate the free flow of information. Thus, the CSR leader must have the skill of influencing across different departments in order to lead such an open system in which information flows freely.

\section{Influencing across external boundaries}

According to Spangenberg and Theron (2011), the different components of an organisation do not function in isolation, but rather operate as different subsystems in a bigger system. External stakeholders are increasingly playing a role in the decision-making processes of organisations and also when it comes to their CSR endeavours (Ferrell et al., 2011). This includes CSR stakeholders such as employees, customers, the government, government agencies, labour unions, the community in which it operates, as well as pressure groups and NGOs (Ferrell et al., 2011; Inyang et al., 2011; Sarma \& Jena, 2006). The importance of responding to all stakeholders is also highlighted in the King III report, whilst B-BBEE legislation also forces companies based in South Africa to take into consideration all stakeholders in the daily performance of their internal and external activities. Leadership in this is needed in an effort to get rid of the social and economic imbalances inherited from the apartheid system and to support formerly discriminated groups in becoming active participants in the economy of the country (Flores-Araoz, 2011). Therefore, it is of utmost importance that sound relations with all the relevant stakeholders are actively pursued by the organisation's CSR leader.

\section{Reviewing performance}

The CSR leader continuously needs to monitor the progress of organisational members in order to take appropriate 
corrective action (if and when necessary). It is not unreasonable to argue that attempts should be made by the CSR leader to direct the performance of organisational members in line with a performance plan that facilitates the implementation of the organisation's CSR vision. It is believed that because the performance of individuals and that of teams do not always meet the required expectations, the leader needs to continuously review individual and CSR performance. These reviews must be done in line with performance plans to ensure that the CSR vision is effectively implemented.

\section{Acknowledging and celebrating performance}

The recognition and celebration of performance provides the final accent by completing the leadership process (Spangenberg \& Theron, 2011). By acknowledging and celebrating performance, organisational members will experience the intrinsic reward of achieving some degree of success for their commitment towards the vision they have been pursuing all along. Recognition is also about acknowledging and celebrating the role that followers play in the unit's successes and about showing that their contributions are appreciated and valued (Spangenberg \& Theron, 2011). It is therefore argued that the CSR leader must create an environment that encourages organisational members to accomplish CSR goals, allows them to experience inner satisfaction and gives them the necessary acknowledgement and rewards when goals are achieved.

The results of Phase 1, namely the CSR leadership stages, roles and dimensions, served as input for Phase 2.

\section{Phase 2: Generation and judging of measurement items}

In total, 119 items of the LBI-2 were revised and 33 new items were developed for the CSR-LQ pilot questionnaire. However, no LBI-2 items were adapted for the two CSR-LQ dimensions CSR leader self-discovery, reflection and selfawareness and displaying sound interpersonal skills, because the LBI-2 items represent generic leadership behaviours that are appropriate in different situations. The newly developed CSR-LQ items were classified according to the structure of the LBI-2 by adding the items to the corresponding dimensions. The rationale behind this decision was the fact that the LBI-2 comprises three actionable phases that are required to successfully implement a vision, which are also relevant to the implementation of a CSR vision.

A two-stream approach was used to improve or delete items, namely: (1) analysing comments on specific items to improve certain items or to delete items and (2) the use of descriptive statistics and numerical decision rules (refer to Table 3).

The comments received were extremely helpful in improving the content and face validity of the items. The comments were implemented by: (1) deleting items that respondents found troublesome or difficult to interpret, (2) merging similar items to create new items and (3) rewording items that were

TABLE 3: Descriptive statistics results for item ratings by expert judges.

\begin{tabular}{|c|c|c|c|}
\hline $\begin{array}{l}\text { Dimension and } \\
\text { associated items }\end{array}$ & $n$ & M & SD $(\sigma)$ \\
\hline \multicolumn{4}{|c|}{ Monitoring the external CSR environment } \\
\hline Item 1 & 13 & 4.08 & 0.64 \\
\hline Item 2 & 13 & 4.08 & 0.64 \\
\hline Item 3 & 12 & 3.50 & 1.09 \\
\hline Item 4 & 13 & 4.15 & 0.99 \\
\hline Item 5 & 12 & 4.33 & 0.78 \\
\hline Item 6 & 12 & 3.67 & 0.98 \\
\hline Item 7 & 13 & 4.46 & 0.66 \\
\hline Item 8 & 13 & 4.15 & 0.90 \\
\hline \multicolumn{4}{|c|}{ Monitoring the internal CSR environment } \\
\hline Item 9 & 13 & 3.62 & 0.87 \\
\hline Item 10 & 13 & 4.08 & 0.64 \\
\hline Item 11 & 13 & 3.92 & 0.76 \\
\hline Item 12 & 13 & 3.62 & 0.87 \\
\hline Item 13 & 13 & 3.77 & 1.01 \\
\hline Item 14 & 12 & 3.75 & 0.97 \\
\hline Item 15 & 12 & 3.92 & 1.00 \\
\hline \multicolumn{4}{|c|}{ Developing a challenging vision } \\
\hline Item 16 & 12 & 4.33 & 0.65 \\
\hline Item 17 & 13 & 4.31 & 0.95 \\
\hline Item 18 & 13 & 4.31 & 0.63 \\
\hline Item 19 & 12 & 4.08 & 1.00 \\
\hline Item 20 & 12 & 4.25 & 0.87 \\
\hline Item 21 & 13 & 3.69 & 0.75 \\
\hline \multicolumn{4}{|c|}{ Conceptualising CSR strategy } \\
\hline Item 22 & 13 & 4.23 & 0.73 \\
\hline Item 23 & 12 & 3.92 & 1.16 \\
\hline Item 24 & 12 & 4.25 & 0.75 \\
\hline Item 25 & 13 & 4.38 & 0.77 \\
\hline Item 26 & 13 & 4.23 & 0.83 \\
\hline Item 27 & 12 & 4.08 & 1.00 \\
\hline Item 28 & 13 & 4.46 & 0.66 \\
\hline Item 29 & 13 & 4.08 & 1.12 \\
\hline \multicolumn{4}{|c|}{ Developing CSR performance plans } \\
\hline Item 30 & 13 & 3.77 & 0.93 \\
\hline Item 31 & 13 & 4.00 & 0.82 \\
\hline Item 32 & 13 & 4.23 & 0.60 \\
\hline Item 33 & 13 & 4.15 & 0.80 \\
\hline Item 34 & 13 & 4.15 & 0.80 \\
\hline Item 35 & 13 & 4.46 & 0.66 \\
\hline Item 36 & 13 & 4.31 & 0.75 \\
\hline \multicolumn{4}{|c|}{ CSR leader self-discovery. reflection and self-awareness } \\
\hline Item 37 & 11 & 4.27 & 0.65 \\
\hline Item 38 & 12 & 4.08 & 0.90 \\
\hline Item 39 & 12 & 4.00 & 1.13 \\
\hline Item 40 & 12 & 4.25 & 0.75 \\
\hline Item 41 & 12 & 4.25 & 0.87 \\
\hline Item 42 & 12 & 4.17 & 1.03 \\
\hline Item 43 & 12 & 4.25 & 0.75 \\
\hline Item 44 & 12 & 4.17 & 0.83 \\
\hline Item 45 & 12 & 4.17 & 0.83 \\
\hline Item 46 & 12 & 4.17 & 0.72 \\
\hline Item 47 & 12 & 4.00 & 0.85 \\
\hline Item 48 & 12 & 4.17 & 1.03 \\
\hline Item 49 & 12 & 4.17 & 0.83 \\
\hline Item 50 & 12 & 4.00 & 0.85 \\
\hline \multicolumn{4}{|c|}{ CSR leader personal growth and development } \\
\hline Item 51 & 13 & 4.00 & 0.82 \\
\hline Item 52 & 13 & 3.62 & 1.19 \\
\hline Item 53 & 13 & 4.31 & 0.63 \\
\hline
\end{tabular}


TABLE 3 (Continues...): Descriptive statistics results for item ratings by expert judges.

\begin{tabular}{|c|c|c|c|}
\hline $\begin{array}{l}\text { Dimension and } \\
\text { associated items }\end{array}$ & $n$ & $M$ & SD ( $\sigma)$ \\
\hline \multicolumn{4}{|c|}{ CSR leader personal growth and development $\uparrow$} \\
\hline Item 54 & 13 & 3.92 & 0.76 \\
\hline Item 55 & 13 & 4.08 & 0.76 \\
\hline Item 56 & 12 & 4.08 & 0.79 \\
\hline Item 57 & 13 & 3.92 & 0.86 \\
\hline Item 58 & 12 & 3.58 & 1.16 \\
\hline Item 59 & 12 & 3.75 & 0.97 \\
\hline \multicolumn{4}{|c|}{ Empowering organisation members } \\
\hline Item 60 & 12 & 3.25 & 1.06 \\
\hline Item 61 & 13 & 3.92 & 0.49 \\
\hline Item 62 & 12 & 3.33 & 0.89 \\
\hline Item 63 & 13 & 4.15 & 0.69 \\
\hline Item 64 & 12 & 2.92 & 0.90 \\
\hline Item 65 & 12 & 3.17 & 1.11 \\
\hline Item 66 & 12 & 3.58 & 1.08 \\
\hline Item 67 & 13 & 4.00 & 0.58 \\
\hline Item 68 & 12 & 3.83 & 0.58 \\
\hline \multicolumn{4}{|c|}{ Optimising processes and structures } \\
\hline Item 69 & 12 & 3.42 & 0.67 \\
\hline Item 70 & 13 & 3.85 & 0.80 \\
\hline Item 71 & 13 & 3.69 & 0.75 \\
\hline Item 72 & 13 & 4.15 & 0.80 \\
\hline Item 73 & 13 & 4.23 & 0.93 \\
\hline Item 74 & 11 & 3.45 & 1.04 \\
\hline Item 75 & 12 & 4.08 & 0.79 \\
\hline Item 76 & 11 & 3.82 & 0.87 \\
\hline \multicolumn{4}{|c|}{ Articulating the CSR vision } \\
\hline Item 77 & 11 & 4.27 & 0.65 \\
\hline Item 78 & 12 & 4.42 & 0.79 \\
\hline Item 79 & 12 & 4.33 & 0.49 \\
\hline Item 80 & 12 & 4.25 & 0.62 \\
\hline Item 81 & 12 & 4.25 & 0.62 \\
\hline Item 82 & 12 & 4.17 & 0.72 \\
\hline Item 83 & 12 & 4.25 & 0.62 \\
\hline Item 84 & 12 & 4.17 & 0.83 \\
\hline \multicolumn{4}{|c|}{ Inspiring and motivating organisation members } \\
\hline Item 85 & 12 & 3.75 & 0.62 \\
\hline Item 86 & 12 & 3.83 & 0.58 \\
\hline Item 87 & 12 & 3.50 & 1.00 \\
\hline Item 88 & 13 & 4.23 & 0.83 \\
\hline \multicolumn{4}{|c|}{ Building trust and demonstrating integrity } \\
\hline Item 89 & 11 & 4.09 & 0.70 \\
\hline Item 90 & 13 & 4.08 & 0.76 \\
\hline Item 91 & 13 & 4.08 & 0.76 \\
\hline Item 92 & 13 & 4.38 & 0.77 \\
\hline Item 93 & 13 & 4.00 & 0.71 \\
\hline Item 94 & 13 & 3.62 & 1.12 \\
\hline Item 95 & 12 & 3.50 & 0.90 \\
\hline Item 96 & 13 & 4.23 & 0.73 \\
\hline Item 97 & 13 & 4.46 & 0.78 \\
\hline \multicolumn{4}{|c|}{ Demonstrating decisiveness and hardiness } \\
\hline Item 98 & 12 & 3.67 & 0.65 \\
\hline Item 99 & 12 & 4.33 & 0.49 \\
\hline Item 100 & 13 & 4.46 & 0.66 \\
\hline Item 101 & 12 & 4.25 & 0.62 \\
\hline Item 102 & 12 & 3.92 & 0.67 \\
\hline Item 103 & 12 & 4.17 & 0.83 \\
\hline Item 104 & 12 & 4.08 & 0.90 \\
\hline
\end{tabular}

TABLE 3 (Continues...): Descriptive statistics results for item ratings by expert judges.

\begin{tabular}{llll}
\hline $\begin{array}{l}\text { Dimension and } \\
\text { associated items }\end{array}$ & $\boldsymbol{n}$ & $\mathbf{M}$ & SD $(\boldsymbol{\sigma})$ \\
\hline Acting entrepreneurial & 12 & & \\
Item 105 & 13 & 3.25 & 1.14 \\
Item 106 & 13 & 3.77 & 0.83 \\
Item 107 & 13 & 4.00 & 0.58 \\
Item 108 & 12 & 4.15 & 0.55 \\
Item 109 & 13 & 3.75 & 0.62 \\
Item 110 & 12 & 3.77 & 0.60 \\
Item 111 & 13 & 4.00 & 0.74 \\
Item 112 & 13 & 3.77 & 0.73 \\
Item 113 & & 3.85 & 0.99 \\
Showing concern for others & 12 & & \\
Item 114 & 12 & 3.58 & 1.31 \\
Item 115 & 12 & 3.58 & 0.67 \\
Item 116 & 12 & 3.67 & 0.78 \\
Item 117 & 12 & 3.75 & 0.45 \\
Item 118 & 12 & 4.25 & 0.62 \\
Item 119 & 12 & 3.75 & 0.75 \\
Item 120 & & 4.08 & 0.67 \\
\hline
\end{tabular}

\section{Displaying sound interpersonal skills}

Item 121

Item 122

Item 123

Item 124

Item 125

Item 126

Item 127

12

0.72

0.60

0.64

0.76

0.58

0.63

\section{Facilitating interdepartmental coordination}

Item 128

Item 129

Item 130

Item 131

Item 132

Item 133

Item 134

Item 135

Item 136

Item 137

Item 138

Item 139

Item 140

Reviewing performance

Item 141

Item 142

Item 143

Item 144

Item 145

Item 146

Item 147

Acknowledging and celebrating performance

Item 148

Item 148

Item 150

Item 151

Item 152

$\mathrm{M}$, mean; SD, standard deviation; CSR, corporate social responsibility $\dagger$, Data continues from previous page.
0.99

0.71

0.51

0.75

0.90

0.75

0.39

0.62

0.76

0.71

0.87

0.95

0.67 0.79

0.87

0.69

0.90

0.64

0.87

0.63

0.69

0.63

0.64

0.44

0.63

0.67 
confusing to the respondents but did show promise. The descriptive statistics were interpreted to retain items that the expert judges felt are relevant to CSR leadership, whilst the means and standard deviations were used to identify those items that had high inter-judge agreement (refer to
Table 3). In most cases, the comments received corresponded with the results of the descriptive statistics. Table 4 depicts how items for the CSR-LQ were modified and retained prior to and after expert judging. An $\mathrm{X}$ indicates inclusion of the item.

TABLE 4: CSR-LQ items prior to and after expert judging.

\section{Dimension and final items}

Pre-judging Final CSR-LQ

Monitoring the external CSR environment

1. Identifies recent developments in the external CSR environment that may affect the company's CSR performance

2. Interprets emerging trends in the external CSR environment that require a proactive response

3. Understands the position of the company's CSR unit or department in the external CSR environment

4. Strives to understand the needs of their customers, suppliers, competitors and the broader community

5. Strives to understand the interrelatedness of CSR with other stakeholders such as customers, employees, suppliers, competitors, government, NGOs and the broader community

6. Interprets emerging business, social and social responsibility trends in the external CSR environment

7. Engages with different external stakeholders such as government and NGOs to determine changes in socio-developmental needs of the communities the organisation operates in

8. Provides opportunities for external stakeholders such as customers, suppliers, competitors, government, NGOs and communities to provide feedback

*Strives to understand the needs of all their stakeholders such as customers, employees, suppliers, competitors, government, NGOs and the broader community

\section{Monitoring the internal CSR environment}

9. Identifies weaknesses in organisational culture that may obstruct accomplishment of the organisation's CSR objectives, e.g. motivation

10. Identifies factors that prevent the organisation from effectively achieving identified CSR objectives

11. Is aware of internal growth or other changes (e.g. change in organisational strategy) that may affect the organisation's CSR objectives

12. Identifies structures that cause problem behaviour in terms of the organisation's CSR mission

13. Creates opportunities for employees to give feedback with regard to the organisation's CSR activities

14. Identifies organisational structures or systems that hamper accomplishment of the organisation's CSR goals

15. Is aware of employees' attitudes and behaviour towards the organisation's social responsibility activities

Developing a challenging CSR vision

16. Generates new ideas and possibilities for the future, in line with the overall strategy of the company

17. Builds a vision and culture that accommodates all relevant stakeholders, including customers, employees, suppliers, competitors and the broader community

18. Develops a clear vision with long-term CSR goals that gives employees a sense of purpose

19. Works at developing a vision that is focused on enhancing society

20. Ensures the CSR vision is focused on stakeholder needs (e.g. needs of customers, employees, suppliers, competitors, government, NGOs and the broader community)

21. Involves employees in the development of the company's CSR vision

*Generates new CSR ideas and possibilities for the future, in line with the overall strategy of the company

*Builds a vision and culture that accommodates the needs of all relevant stakeholders, including customers, employees, suppliers, competitors and the broader community

\section{Conceptualising CSR strategy}

22. Develops CSR plans that are based on sufficient information from sources within (e.g. employees, other departments) and outside (e.g. $\quad X$ NGOs, government) the organisation

23. Identifies the root causes of problem areas

24. Defines strategic issues clearly

25. Understands the longer-term business consequences of CSR decisions

26. Develops CSR plans that are in line with the company's overall strategy

27. Develops CSR strategy that is based on sufficient information from sources within and from outside the organisation

28. Converts the CSR vision into clearly formulated strategic plans

29. Understands the business case for CSR

Developing CSR performance plans

30. Provides clarity about what is expected from employees in terms of CSR

31. Plans the implementation of CSR initiatives to fit the needs of the organisation

32. Ensures that employee, team and departmental goals are aligned with the CSR strategy of the organisation

33. Ensures CSR plans support the organisation's strategic plan

34. Sets specific CSR targets that are aligned with the organisation's overall CSR vision

35. Determines measurement criteria for the attainment of the CSR targets and performance

36. Implements CSR performance appraisal against the set criteria

CSR leader self-discovery, reflection and self-awareness

37. Is open to feedback

38. Realises when their own behaviour is unsuitable and takes corrective action

39. Manages time effectively

40. Welcomes constructive criticism

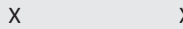


TABLE 4 (Continues...): CSR-LQ items prior to and after expert judging.

Dimension and final items

\section{CSR leader self-discovery, reflection and self-awareness}

41. Has good insight into their own strengths and weaknesses

42. Continuously reflects on their own behaviour and how it can be improved

43. Views constructive criticism as a learning opportunity to improve future performance

44. Is aware of emotions in self and expresses them appropriately

45. Is open to feedback about how their behaviour affects other people

46. Is able to understand the emotions of others

47. Is able to manage own emotions

48. Manages themselves effectively

49. Realises when their own behaviour is inappropriate and takes corrective action

50. Is able to control own emotions

*Is able to manage and control own emotions

CSR leader personal growth and development

51. Identifies challenging CSR projects and opportunities to develop their own competence

52. Experiments with new ways of doing things, even if there are risks involved

53. Commits themselves to personal development and continuous learning in the field of CSR

54. Considers change in the CSR field as a challenge and an opportunity for growth

55. Continuously stays abreast with the latest developments in the CSR field (e.g. attends CSR conferences, networking events, courses, subscribes to newsletters)

56. Actively develops their own competence

57. Engages with peers in the field to identify new CSR projects to get involved with

58. Tries new approaches rather than rigidly adhering to conventional methods

59. Commits themselves to career development (e.g. attending leadership courses, has a personal mentor or coach)

\section{Empowering organisation members}

60. Helps organisation members to develop their strengths and improve their weaknesses

61. Supports employee participation (e.g. CSR decision-making, planning of CSR initiatives)

62. Gets followers to regularly assess work progress and learn better ways to do their work

63. Works at creating a sense of ownership for the organisation's social responsibility or the CSR initiatives followers are involved in

64. Creates conditions that enable employees to work undisturbed

65. Changes the way people work together when required

66. Encourages organisation members to learn from situations when things did not go as planned

67. Purposefully promotes CSR learning throughout the organisation

68. Promotes continuous learning with regard to social responsibility purposefully throughout the organisation

*Purposefully promotes learning with regard to social responsibility throughout the organisation

\section{Optimising processes and structures}

69. Revises the practices of the organisation to adapt to changes in the CSR environment

70. Adapts the structures and core processes of the organisation to support implementation of the company's CSR strategy

71. Ensures that the CSR policies and procedures of the organisation support work performance

72. Works at creating a high performance CSR work culture in the organisation

73. Clarifies roles and responsibilities (who does what) before setting CSR performance goals

74. Creates a work environment that facilitates effective performance by organisation members

75. Revises CSR structures and processes when the organisation's CSR strategy changes

76. Promotes open communication throughout organisation

*Promotes open CSR communication throughout organisation

\section{Articulating the CSR vision}

77. Articulates a clear and challenging vision for CSR

78. Envisions a future with regard to corporate responsibility that excites followers and releases energy in the organisation

79. Conveys a sense of mission that inspires commitment to CSR in followers

80. Shows a clear sense of direction in terms of where the organisation is going with CSR

81. Excites employees to take part in the company's CSR initiatives through leading by example

82. Helps employees make sense of CSR vision by linking it to the company's overall strategy

83. Communicates a CSR vision that provides direction and focuses organisation members' energy towards the CSR vision

84. Inspires organisation members' commitment to the organisation's CSR mission

Inspiring and motivating organisation members

85. Increases the willingness of organisation members to put in more effort to get involved in the organisation's social responsibility activities and initiatives

86. Raises the CSR aspirations of organisation members and develops their potential

87. Builds confidence in organisation members to perform effectively

88. Conveys ideas and proposals with regard to the organisation's social responsibility convincingly

Building trust and demonstrating integrity

89. Acts in a transparent way: employees know what they stand for in the organisation

90. Puts the well-being of the organisation's CSR initiatives above own interest
$\mathrm{X}$

$x$

$x$

$-$

$\mathrm{X}$

$-$

$\mathrm{x}$

$\begin{array}{ll}x & x \\ x & x \\ x & x \\ x & x \\ x & x \\ x & x \\ x & x \\ x & x \\ x & x \\ x & x \\ x & - \\ x & x\end{array}$

\section{$x$}

$x$

$x$

$x$ 
TABLE 4 (Continues): CSR-LQ items prior to and after expert judging.

\section{Dimension and final items}

\section{Building trust and demonstrating integrity}

91. Ensures that their behaviour supports the values of the organisation's

92. Considers organisational as well as ethical implications of decisions

93. Builds confidence in the purpose and direction of the organisation's CSR strategy in organisation members

94. Holds individuals accountable for behaviours that are not in line with organisation CSR values

95. Earns respect for results they have achieved

96. Deals honestly with all stakeholders (e.g. employees, colleagues, community members)

97. Delivers on promises to stakeholders (e.g. employees, colleagues, NGOs, community members)

\section{Demonstrating decisiveness and hardiness}

98. Acts quickly and decisively

99. Shows credibility and confidence even in difficult situations

100. Is prepared to make tough decisions concerning the organisation's social responsibility

101. Reacts positively to change and uncertainty

102. Positively exploits organisational change

103. Reacts decisively in response to change and uncertainty

104. Can make CSR decisions that are not always popular with stakeholders, but in the best interest of the beneficiary or company (e.g. cut funding to force beneficiary to become more independent)

\section{Acting entrepreneurial}

105. Takes considerable CSR risks for the benefit of the organisation

106. Questions the way in which the organisation's CSR is currently being carried out

107. Grasps new CSR opportunities to accomplish the organisation's CSR goals

108. Seeks innovative alternatives for improving the organisation's CSR functions

109. Accepts organisational change

110. Promotes new CSR ideas and projects for the organisation

111. Is continuously on the lookout for opportunities to improve the organisation's social responsibility

112. Takes calculated risks for the benefit of CSR in the organisation

113. Does a cost-benefit analysis of the CSR opportunities that present themselves

\section{Showing concerns for others}

114. Develops full understanding for the problems of organisation members

115. Acknowledges that each organisation member has needs and aspirations

116. Encourages organisation members to express their ideas or feelings

117. Shows concern for the needs and feelings of others

118. Treats diverse individuals with dignity and respect

119. Understands how followers think and feel about their work

120. Takes active attempts to build a relationship with CSR members

\section{Displaying sound interpersonal skills}

121. Obtains different viewpoints when solving problems

122. Listens carefully to understand different viewpoints when solving problems

123. Deals with problems around human diversity in a constructive manner

124. Proactively works through conflicts

125. Listens with openness and understanding

126. Obtains viewpoints from relevant stakeholders when solving CSR problems

127. Adapts their leadership style to address the needs of diverse individuals and groups *Obtains different viewpoints from relevant stakeholders when solving CSR problems

Facilitating inter-departmental coordination

128. Stimulates collaboration and teamwork across departments or sections in order to reach the organisation's CSR objectives

129. Encourages different departments or sections to operate in a coordinated, interdependent fashion

130. Helps organisation members see the big picture of social responsibility by explaining links between different strategies, processes and projects

131. Shows capability to manage across different functions or units

132. Promotes the continuous flow of CSR information between different departments or sections

133. Helps sections or departments to work well together by explaining the wider CSR picture

134. Shows capability to manage CSR strategies and processes across sections or departments

135. Encourages different departments or sections to share resources in order for the organisation to achieve the organisation's overall CSR goals and objectives

\section{Influencing across external boundaries}

136. Builds the organisation's social responsibility image

137. Builds the image of the CSR industry or profession

138. Listens to the needs of all relevant stakeholders (e.g. customers, employees, suppliers, competitors, government, NGOs and the broader community) regarding the organisation's CSR activities

139. Gets involved in community-related initiatives: practises socially responsible citizenship

140. Addresses public responsibility issues: practises good citizenship

$\begin{array}{ll}x & - \\ x & x \\ x & x \\ x & x \\ x & x \\ x & x \\ x & x \\ x & x \\ x & x \\ x & \\ x & - \\ x & x \\ x & x \\ x & x \\ x & x \\ x & x \\ & x\end{array}$

\section{(1)}




\begin{tabular}{|c|c|c|}
\hline Dimension and final items & Pre-judging & Final CSR-LQ \\
\hline \multicolumn{3}{|l|}{ Reviewing performance } \\
\hline 141. Gives specific feedback to help employees achieve their goals & $\mathrm{x}$ & $\mathrm{x}$ \\
\hline 142. Provides feedback to organisation members about the organisation's CSR performance & $\mathrm{x}$ & $\mathrm{x}$ \\
\hline 143. Measures organisation members in terms of achieving their goals & $\mathrm{x}$ & $\mathrm{x}$ \\
\hline 144. Provides continuous performance feedback to organisation members in terms of their CSR performance & $\mathrm{x}$ & $\mathrm{x}$ \\
\hline 145. Measures employees' performance in terms of achievement of agreed upon CSR goals & $\mathrm{x}$ & $\mathrm{x}$ \\
\hline 146. Continuously shares the results and outcomes of the organisation's social responsibility endeavours with organisation members & $\mathrm{x}$ & $\mathrm{x}$ \\
\hline $\begin{array}{l}\text { 147. Regularly obtains feedback from external stakeholders (e.g. communities, government, NGOs) with regard to the organisation's CSR } \\
\text { performance }\end{array}$ & $\mathrm{x}$ & $\mathrm{x}$ \\
\hline \multicolumn{3}{|l|}{ Acknowledging and celebrating performance } \\
\hline 148. Gives recognition to members for successful completion of CSR initiatives or meeting CSR performance goals & $\mathrm{x}$ & $\mathrm{x}$ \\
\hline 149. Expresses appreciation for what employees contribute to the organisation in terms of CSR & $\mathrm{x}$ & $\mathrm{x}$ \\
\hline 150. Celebrates the organisation's major CSR achievements & $\mathrm{x}$ & $\mathrm{x}$ \\
\hline 151. Gives recognition to employees for positive behaviour and attitude in carrying out their duties & $\mathrm{x}$ & - \\
\hline 152. Expresses appreciation towards organisation members who advance the organisation's CSR goals & $\mathrm{x}$ & $\mathrm{x}$ \\
\hline
\end{tabular}

CSR, Corporate social responsibility leadership questionnaire

$*$, merged/reworded items

$\uparrow$, Data continues from previous page.

\section{Phase 3: Finalisation of the CSR-LQ prior to empirical testing}

After the completion of the data analysis, the final version of the CSR-LQ was developed (refer to Table 4, last column). In total, 36 items were deleted from the pilot CSR-LQ questionnaire, whilst seven new items were added through the merging of items. The final version of the CSR-LQ hence consists of 123 items.

\section{Limitations}

This study had limitations due to time, economic and practical constraints. The general conclusions drawn are based on the information gathered from the respondents. As mentioned in the literature review, there is a lack of research on the intersection between CSR and leadership (Strand, 2011; Waldman \& Siegel, 2008). South African research studies on CSR and leadership are even more scant. This research attempted to shed light on the topic of CSR leadership and did not attempt to cover all the available literature on the topic.

The study was limited to large organisations in the private sector in South Africa, which imposes limitations on the generalisation of the study's results to small and mediumsized businesses, as well as organisations outside of South Africa. The fact that only CSR leaders took part in the development process of the CSR-LQ could be considered a limitation as the study set out to develop a CSR leadership measurement instrument that could be used to obtain $360^{\circ}$ assessments of CSR leadership competencies. If direct followers and peers of CSR leaders were included in the sample it could have impacted on the results. However, this is not viewed as a limitation since it was believed that the subject experts know the field of CSR leadership the best and that followers and peers can be included in the empirical testing of the instrument at a later stage.

The basic principles of the CIT and the Delphi techniques were used during the first and second phases of the CSR-LQ development process; however, not all the methodological guidelines provided for the implementation of these techniques could be adhered to within the scope and sample constraints of this study. This could be regarded as a major limitation of this study; however, we contend that this study still contributes toward the development of a CSR-LQ as this study is the first step toward this goal.

The low response rate (approximately 22\%) of private sector participants during the second phase of the research and the total sample size of 18 ( $n=5$ during the first phase and $n=13$ during the second phase) may be considered as not having provided a representative pool of judgements regarding CSR leadership.

The language used throughout the study (during the interviews and in the measurement instrument) could be considered a limitation. Although the items of CSR-LQ were in English, English is the home language of only three out of the 13 expert judges who took part in the judging of the CSR-LQ items. This could have had an adverse effect on how the judges understood the items, which might have had an impact on how they rated the relevance of each item.

An alternative leadership model or measurement instrument could have been chosen to form the basis of the CSR-LQ. In this study, the neo-charismatic leadership paradigm was chosen as the paradigm in which CSR leadership falls and the LBI-2, as developed by Spangenberg and Theron (2010, 2011), was proposed to form the basis of the CSR leadership measurement instrument that was developed. Alternative leadership models could have been chosen and different leadership theories could have offered different results.

The methodology employed in the development of the CSRLQ did not include a scale purification phase in which the reliability and validity of the items were studied. Despite these limitations, it is still believed that the results of this study are relevant and could contribute to future research in CSR leadership. 


\section{Recommendations for future research}

The main motivation for developing the CSR-LQ was to develop a measure of CSR leadership competence to enable the eventual development and empirical testing of a CSR leadership competency model. It is therefore recommended that the CSR-LQ measurement instrument firstly be revised once more using the critical incident and Delphi techniques according to the methodological rigour as proposed by scholars. Secondly, the CSR-LQ should be validated using structural equation modelling (SEM). The SEM process is based on covariances that are less stable when estimated from small samples and thus a large sample of CSR leaders with one or more followers would be needed. Once the SEM process has been completed and credible evidence on the reliability and construct validity of the instrument exists, the CSR-LQ can be used with confidence to operationalise the 20 latent behavioural CSR leadership dimensions as presented in the model. Once the CSR-LQ has been validated (meaning that the competencies of a successful CSR leader have been identified) future researchers can focus on identifying the outcomes of CSR leadership and continue with the development of a comprehensive CSR leadership competency model.

\section{Conclusion}

Since this study was the first step toward the development of a comprehensive, all-inclusive CSR leadership competency model, it is premature to draw conclusions regarding the instrument; conclusions can only be made after the CSR leadership measurement instrument that was developed undergoes a further phase of redevelopment and empirical testing. However, based on the data gathered from the 18 respondents (representing various industries' representatives) during the development of the CSR-LQ, six tentative conclusions, with regard to CSR in general, can be drawn.

Firstly, the CEO, assisted by the group or company secretary, is primarily responsible for setting the organisation's policy on CSR and providing oversight, whilst specific positions are then created to implement the organisation's CSR strategy and to coordinate the various components of their CSR initiatives. Secondly, some South African companies are committed to CSR and realise its importance as a way to address South Africa's societal and environmental issues. They also see the business benefits of engaging in CSR and view it as part of their competitive advantage. Thirdly, although the terms corporate social responsibility and corporate social investment have different meanings, the two terms are used interchangeably by many South African organisations. Fourthly, the release of the draft National Development Plan (NDP) entitled 'Vision for 2030' in November 2011 and the acceptance of the revised NDP 2030 entitled 'Our future make it work' by the South African parliament in August 2012 impacted the CSR strategy and CSR initiatives of many South African companies. The NDP motivated companies to review and revise their CSR strategies and to align their CSR outcomes with the NDP in order to assist the country in achieving the plan's stated objectives. Fifthly, many South African organisations align their CSR strategies with their core competencies and use their available resources to achieve their stated CSR outcomes and, lastly, in order to successfully implement CSR throughout the organisation, it is important to make it part of the organisation's culture.

\section{Acknowledgements Competing interests}

The authors declare that they have no financial or personal relationships that may have inappropriately influenced them in writing this article.

\section{Authors' contributions}

R.D.P. (Stellenbosch University) was the supervisor of L.T.v.Z. (Stellenbosch University) for his Master of Commerce (Industrial Psychology) dissertation. The article flows from his research in this regard.

\section{References}

Aguinis, H., \& Glavas, A. (2012). What we know and don't know about corporate social responsibility: A review and research agenda. Journal of Management, 38(4), 932-968. http://dx.doi.org/10.1177/0149206311436079

Bass, B.M., \& Avolio, B.J. (2008). Manual for the Multifactor Leadership Questionnaire: Manual and sampler set. Palo Alto, CA: Mind Garden.

Borgen, W., Amundson, N., \& Butterfield, L. (2008). Critical incident technique. In L.M. Given (Ed.), The Sage Encyclopedia of qualitative research methods (pp. 159-160). Thousand Oaks, CA: SAGE Publications, Inc. http://dx.doi. org/10.4135/9781412963909.n84

Butterfield, L.D., Borgen, W.A., Amundson, N.E., \& Maglio, A.S.T. (2005). Fifty years of the critical incident technique: 1954-2004 and beyond. Qualitative Research, 5(4), 475-497. http://dx.doi.org/10.1177/1468794105056924

Carroll, A.B. (1991). The pyramid of corporate social responsibility: Toward the moral management of organizational stakeholders. Business Horizons, 34(4), 39-48. $\mathrm{http}: / / \mathrm{dx}$.doi.org/10.1016/0007-6813(91)90005-G

Carroll, A.B., \& Shabana, K.M. (2010). The business case for corporate social responsibility: A review of concepts, research and practice. International Journal of Management Review, 12(1), 85-105. http://dx.doi.org/10.1111/j.1468 2370.2009.00275.x

Du, S., Bhattacharya, C.B., \& Sen, S. (2010). Maximizing business returns to corporate social responsibility (CSR): The role of CSR communication. International Journal of Management Reviews, 12(1), 8-19. http://dx.doi.org/10.1111/j.14682370.2009.00276.x

Ferrell, O.C., Thorne, D.M., \& Ferrell, L. (2011). Social responsibility \& business. SouthWestern Cengage Learning. Mason: $\mathrm{OH}$

Flanagan, J.C. (1954). The critical incident technique. Psychological Bulletin, 51(4), 327-358. http://dx.doi.org/10.1037/h0061470

Flores-Araoz, M. (2011). Corporate social responsibility in South Africa: More than a nice intention. Retrieved July 09, 2013, from http://www.consultancyafrica. com/index. php?option $=$ com_content $\&$ view $=$ article \&id $=835$ : corprate-socialresponsibility-in-south-africa-more-than-a-niceintention\&catid=82: africanindustry-a-business\&ltemid $=266$

Fuller, M.A. (2008). Social capital as a form of non-economic competition: Observations from the Canadian financial services sector. Administration Sciences Association of Canada, 29(29) 55-71.

Harari, O. (1997). Looking beyond the vision thing. Management Review, 86(6), 26-29.

House, R.J. (1995). Leadership in the twenty-first century. In A. Howard (Ed.), The changing nature of work (pp. 411-450). San Francisco, CA: Jossey-Bass.

Inyang, B.J., Awa, H.O., \& Enuoh, R.O. (2011). CSR-HRM nexus: Defining the role engagement of the human resources professionals. International Journal of Business and Social Science, 2(5), 118-126.

Kakabadse, N.K., Kakabadse, A.P., \& Lee-Davies, L. (2009). CSR leaders road-map. Corporate Governance, 9(1), 50-57. http://dx.doi. org/10.1108/14720700910936056

Lacerda, T.C.D. (2010). Transformational leadership: Toward a strategy of corporate social responsibility. Saarbrücken: LAP Lambert Academic Publishing.

Latham, G.P., \& Wexley, K.N. (1994). Increasing productivity through performance appraisal. Reading, MA: Addison-Wesley.

Luo, X., \& Bhattacharya, C.B. (2006). Corporate social responsibility, customer satisfaction, and market value. Journal of Marketing, 70(4), 1-18. http://dx.doi. org/10.1509/jmkg.70.4.1 
Maon, F., Lindgreen, A., \& Swaen, V. (2009). Designing and implementing corporate social responsibility: An integrative framework grounded in theory and practice. Journal of Business Ethics, 87(1), 71-89.

Matten, D., Crane, A., \& Chapple, W. (2003). Behind the mask: Revealing the true face of corporate citizenship. Journal of Business Ethics, 45(1), 109-120. http://dx.doi. org/10.1023/A:1024128730308

McElhaney, K. (2009). A strategic approach to corporate social responsibility. Leader to Leader, 52(1), 30-36. http://dx.doi.org/10.1002/Itl.327

McWilliams, A., \& Siegel, D.S. (2001). Corporate social responsibility: A theory of the firm perspective. The Academy of Management Review, 26(1), 117-127. http:// dx.doi.org/10.5465/AMR.2001.4011987

Miczo, N. (2003). Beyond the 'fetishism of words': Considerations on the use of the interview to gather chronic illness narratives. In P. Atkinson, \& S. Delamont (Eds.), SAGE qualitative research methods (pp. 470-193). Retrieved July 09, 2013, from http://srmo.sagepub.com/view/sage-qualitative-research-methods/SAGE.xml

Minghat, A.D., Yasin, R.M., \& Udin, A. (2012). The application of the Delphi technique in technical and vocational education in Malaysia. International Proceedings of Economics Development and Research, 30(1), 259-264.

Mishra, S., \& Suar, D. (2010). Does corporate social responsibility influence firm performance of Indian companies? Journal of Business Ethics, 95(4), 571-601. http://dx.doi.org/10.1007/s10551-010-0441-1

Morgeson, F.P., Aguinis, H., Waldman, D.A., \& Siegel, D.S. (2013). Extending corporate social responsibility research to the human resource management and organizational behavior domains: A look to the future. Personnel Psychology, $66(4), 805-824$.

Nadler, D.A., \& Tushman, M.L. (1990). Beyond the charismatic leader: Leadership and organizational change. California Management Review, 32(2), 77-97. http:// dx.doi.org/10.2307/41166606

Netemeyer, R.G., Bearden, W.O., \& Sharma, S. (2003). Scaling procedures. Issues and applications. Thousand Oaks, CA: Sage.

National Planning Commission (NPC). (2011). National development plan. Pretoria: NPC

Pedersen, E.R. (2006). Making corporate social responsibility (CSR) operable: How companies translate stakeholder dialogue into practice. Business and Society Review, 111(2), 137-163. http://dx.doi.org/10.1111/j.1467-8594.2006.00265.x

Phillips, S. (2013). Corporate social responsibility: Fast becoming the popular kid on the corporate playground. Retrieved May 07, 2015, from http://www.phinc.co.za/ NewsPublications/NewsArticle.aspx?CategoryID=1\&articleld=632-.VVJCzdqqqkp

Podsakoff, P.M., MacKenzie, S.B., Moorman, R.H., \& Fetter, R. (1990). Transformational leader behaviors and their effects on followers' trust in leader, satisfaction, and organizational citizenship behaviors. The Leadership Quarterly, 1(2), 107-142. http://dx.doi.org/10.1016/1048-9843(90)90009-7

Porter, M.E., \& Kramer, M.R. (2006). Strategy and society: The link between competitive advantage and corporate social responsibility. Harvard Business Review, 84(12), 78-92.
Robbins, S.P., Odendaal, A., \& Roodt, G. (2003). Organisational behaviour: Global and Southern African perspectives. Cape Town: Pearson Education South Africa.

Sarma, P., \& Jena, L. (2006). Corporate social responsibility: An indispensable tool for corporate growth and survival. Growth, 34(1), 15-20.

Spangenberg, H.H., \& Theron, C.C. (2002). Development of a uniquely South African leadership questionnaire. South African Journal of Psychology, 32(2), 9-25. http:// dx.doi.org/10.1177/008124630203200202

Spangenberg, H.H., \& Theron, C.C. (2010). Leadership behaviour inventory (LBI-2) manual: Guidelines for administration, scoring and interpretation. Stellenbosch: Stellenbosch University.

Spangenberg, H.H., \& Theron, C.C. (2011). LBI-2 development report: Leadership report and planning guide. Pinegowrie: Jopie van Rooyen.

STATISTICA version 8.0 [Computer software] (2007). Tulsa, OK: StatSoft, Inc.

Statistics South Africa (StatsSA). (2012). Standard industrial classification of all economic activities (SIC). (7th edn.). Pretoria: StatsSA.

Strand, R. (2011). Exploring the role of leadership in corporate social responsibility: A review. Journal of Leadership, Accountability, and Ethics, 8(4), 84-96.

Strandberg, C., \& Principal, S.C. (2009). The role of human resource management in corporate social responsibility issue brief and roadmap. Burnaby: Strandber Consulting.

Su, Y., Win, K.T., \& Chung, T. (2010). Applying the modified Delphi method to identify the Taiwanese electronic health record systems evaluation framework and instrument. Proceedings of the 14th Pacific Asia Conference on Information Systems (PACIS 2010) (pp. 693-704). Taiwan: National Taiwan University.

Turner, N., Barling, J., Epitropaki, O., Butcher, V., \& Milner, C. (2002). Transformational leadership and moral reasoning. Journal of Applied Psychology, 87(2), 304-311. http://dx.doi.org/10.1037/0021-9010.87.2.304

Van den Ende, L. (2004). Corporate social responsibility in South Africa: Fact or fiction? Unpublished master's thesis, Department of Business Management, Rand Afrikaans University, Johannesburg, South Africa.

Van Zyl, L.T. (2013). Toward the development of a corporate social responsibility leadership questionnaire. Unpublished master's thesis, Department of Industrial Psychology, Stellenbosch University, Stellenbosch, South Africa.

Waldman, D.A., \& Siegel, D. (2008). Defining the socially responsible leader The Leadership Quarterly, 19(1), 117-131. http://dx.doi.org/10.1016/j. leaqua.2007.12.008

Waldman, D.A., Siegel, D. \& Javidan, M. (2006). Components of CEO transformational leadership and corporate social responsibility. Journal of Management Studies, 43(8), 1703-1725. http://dx.doi.org/10.1111/j.1467-6486.2006.00642.x

Were, M. (2003). Implementing corporate responsibility - The Chiquita case. Journa of Business Ethics, 44(2), 247-260. http://dx.doi.org/10.1023/A:1023316303587

Yukl, G.A. (2010). Leadership in organizations. Upper Saddle River, NJ: Pearson Education. 